\title{
PETROLOGY OF THE SHELBURNE AND BARRINGTON PASSAGE PLUTONS, SOUTHERN NOVA SCOTIA
}

\author{
H. Dean Rogers and Sandra M. Barr \\ Department of Geology, Acadla University \\ Wolfville, Nova Scotia BOP 180
}

Date Received December 3, 1987

Date Accepted February 25, 1988

\begin{abstract}
The Shelburne and Barrington Passage plutons are adjacent, but contrasting, Intrusions located on the southern coast of Nova Scotia. The Shelburne Pluton consists mainly of monzogranite and granodiorite, with minor artas of tonalite, whereas the Barrington Passage pluton consists of tonalite gradational to quartz diorite. Both plutons have petrochemical characteristics consistent with derivation from metasedimentary source rocks. Major and trace element trends within the Barrington Passage tonalite suggest that magma evolution was controlled by biotite fractionetion. whereas plagioclase and biotite fractionation may have produced much of the variation within the Shelburne Pluton. Tonalite within the Shelburne Pluton has higher Sr than the Barrington Passage tonalite, and may have formed by
\end{abstract} plagioclase accumulation from co-magmatic granodiorite and monzogranite of the Shelburne Piuton.

On the basis of previously published Ar data, the Barrington Passage Pluton was probably emplaced during the mair. phase of regional metamorphism related to the Acadian Orogeng (about $400 \mathrm{Ma}$ ). A Rb-Sr whole-rock isochron suggests an age of $466 \pm 17 \mathrm{Ma}$ for the Shelburne Pluton, although published Ar data have Indicated a Devonian age. The ages of these plutons and others in the southernmost Meguma Terrane must be better constrained before a reliable assessment of petrogenesis and tectonic history can be made.

Les plutons de Shelburne et Barrington Passage sont des 1ntrusions adjacentes qui contrastent et sont situees sur la côte meridionale de la Nouvelle-Ecosse. Le Pluton de Shelburne se compose surtout de monzogranite et granodiorite ponctuées de tonalite: par contre, le Pluton de Barrington Passage est forme de tonalite passant graduellement à une dior1te quartzique. Les caractéres pétrochimiques de ces deux plutons s'accordent avec une provenance métasédimentaire. A la lumière des elèments majeurs et en traces, le fractionnement de la blotite semble avoir conditionne l'evolution magmatique de la tonalite de Barrington Passage alors que la variation dans le Pluton de Shelburne semble assujettie en grande partie au fractionnement du plagioclase et de la biotite. La tonalite présente dans le Pluton de Shelburne renferme une plus grande proportion de Sr que la tonalite de Barrington Passage et pourrait avo1x procédé de l'accumulation de plagioclase à partir d'un mélange magmatique de granodiorite et monzogranite.

S1 on en juge par les données dejà publiées sur l'argon, le Pluton de Barrington Passage s'est probablement mis en place durant la phase principale de métamorphisme régional reliée à l'orogenie acadienne (environ 400 Ma). Un 1sochrone $\mathrm{Rb}-\mathrm{Sr}$ sur roche entière suggère un age de $466 \pm 17$ Ma pour le Pluton de Shelburne même si l'information publiè sur l'argon a 1ndiqué un âge dévonien. On se dōt de préciser l'âge de ces intrusions ainsi que des autres plutons dans la partie la plus méridionale de la Lanière de Méguma si on veut lever tout doute sur leur pétrogenése et leur histoire tectonique.

[Traduit par le journal]

\section{INTRODUCTION}

The Shelburne and Barrington Passage plutons (Taylor, 1967) are located in the Meguma Terrane of Nova Scotia, south of the South Mountain Batholith (Fig. 1). Most previous studies (Taylor, 1967; de Albuquerque, 1977; Longstaffe et al., 1980; Reynolds et al., 1981, 1984) have indicated that these plutons differ significantly in composition, petrogenesis, and possibly age from each other and from the South Mountain Batholith, although recent geochronological studies by Reynolds et al. (1987) have indicated that the Shelburne Pluton is similar in age to the South Mountain Batholith (about 370 $\mathrm{Ma}$ ) and that the Barrington Passage Pluton may be only slightly older (minimum age $385 \mathrm{Ma}$ ). Smith (1979) suggested that all of these plutons were derived from the same clastic metasedimentary source, but that they are exposed at different levels in their intrusive systems and hence represent different stages of magma evolution, which Smith (op cit.) suggested was controlled mainly by differentiation processes. In contrast, de Albuquerque (1977) and Longstaffe et al. (1980) postulated variations in degree of partial melting and/or source rock composition to explain the differences.

Previous petrological interpretations of the Shelburne and Barrington Passage plutons were based on reconnaissance field mapping and limited sampling. The purpose of this paper is to summarize the results of more detailed field mapping and petrochemical studies of these plutons, done as part of a regional mapping project in the Shelburne area (Rogers and White, 1984; Rogers, 1986). A total of two hundred and fifty samples were collected from the plutons for petrographic study, and 46 of these samples were analyzed for major elements and a large suite of trace elements. These data, together with petrographic descriptions and sample locations, will be presented by Rogers (in preparation), and only summarles are included here. Samples from de Albuquerque (1977), for which modal analyses and major and trace element data are avallable, also are included for comparison. This report documents the range of 11thologies within each pluton and shows that both intrusions are internally more complex than previously demonstrated.

Although earlier maps (Taylor, 1967; Keppie, 


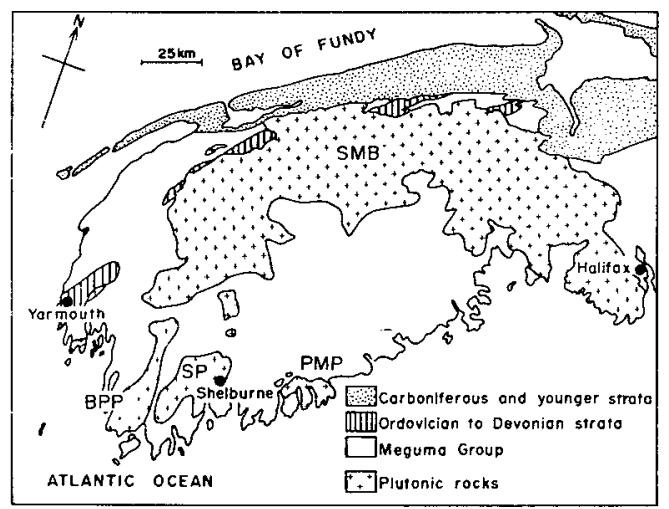

Fig. 1. Simplified geological map of the southern part of the Meguma Terrane, showing the locations of the Barrington Passage (BPP), Shelburne (SP), and Port Mouton (PMP) plutons and the South Mountain Batholith (SMB).

1979) have generally shown the Barrington Passage and Shelburne plutons to be juxtaposed, isolated metasedimentary outcrops in the intervening area indicate that the plutons are not in contact at the present level of exposure (Rogers and White, 1984; Rogers, 1986). No cross-cutting relations have been observed between the two plutons, and their relative ages are not known.

\section{GEOLOGICAL SETTING}

The Shelburne and Barrington Passage plutons intruded metasedimentary rocks of the Meguma Group (Fig. 2), which includes the Goldenville and Halifax Formations. The Goldenville Formation consists of a thick sequence of psammitic and minor pelitic rocks, and the overlying Halifax Formation is dominantly pelitic. Age controls are limited, but the Goldenville Formation is generally inferred to be Cambrian and the Halifax Formation Late Cambrian to Early Ordovician in age, based on sparse fossil occurrences (e.g., Keppie, 1979).

These units were folded during a regional deformational event (the Acadian Orogeny) accompanied by regional metamorphism at about $410-$ $400 \mathrm{Ma}$ (Reynolds and Muecke, 1978; Dallmeyer and Keppie, 1987). Elsewhere in southern Nova Scotia, regional metamorphism generally reached chlorite and biotite grade, but in the vicinity of the Shelburne and Barrington Passage plutons, the grade increases to sillimanite, although the relative effects of regional and contact metamorphism are not entirely resolved (Chu, 1978; Keppie and Muecke, 1979; Raeside et al., 1985; Dallmeyer and Keppie, 1987). Raeside et al. (1985) suggested that regional metamorphism in the area attained at least staurolite-andalusite grade, and that the isograds are folded, indicating that deformation continued after the peak of regional metamorphism. The sillimanite isograd follows the margins of the Barrington Passage Pluton, with anatectic migmatites developed in pelitic layers in a zone of variable width up to $1 \mathrm{~km}$ surrounding the pluton (Bourque, 1985). This suggests that emplacement of the pluton resulted in an increase in metamorphic grade in adjacent rocks, producing sillimanitepotassium feldspar assemblages and the cordieritebearing migmatites. In contrast, migmatites were not developed around the margins of the Shelburne
Pluton and the andalusite-sillimanite isograd appears to intersect the pluton, rather than following its margins, suggesting that the pluton may have either pre-dated or post-dated the metamorphic event. Wentzell (1985) interpreted zoning in garnets in metamorphic rocks near the Shelburne pluton to have formed from two-stage metamorphism, involving first contact and then regional metamorphic overgrowths, suggesting that the pluton may pre-date the peak of regional metamorphism. On the basis of the inferred metamorphic history, Raeside et al. (1985) interpreted the Shelburne Pluton to be older than the Barrington Passage Pluton, and suggested that up to $5 \mathrm{~km}$ of uplift occurred between the times of emplacement of the two intrusions. However, this interpretation is not generally consistent with recent geochronological studies which suggest that the two plutons are of similar age (Dallmeyer and Keppie, 1987; Reynolds et al., 1987), and the timing of intrusive and metamorphic events in the Shelburne area remains enigmatic (see section on age for further discussion).

\section{SHELBURNE PLUTON}

\section{Field Relations and Petrography}

The Shelburne Pluton consists mainly of monzogranite and granodiorite (Fig. 3). De Albuquerque (1977) described the rocks of the pluton as trondhjemitic, and on the basis of chemical parameters (see below) at least some samples (including those analyzed for rare-earth elements by de Albuquerque, 1977) can be classified as trondhjemite. However, these samples contain significant amounts (8-15\%) of biotite $( \pm$ muscovite) and plot in the granodiorite field on the quartz-alkali feldspar-plagloclase ternary diagram ( Fig. 3), and hence herein are referred to as granodiorite. Distinction between monzogranite and granodiorite is difficult in the field, and no contacts between the two lithologies were observed; their relationship is interpreted to be gradational.

Tonalite also occurs 1ocally within the Shelburne Pluton. Its relationship to the monzogranitegranodiorite is not clear; in one outcrop it appears to be mixed with (and possibly xenolithic in) monzogranite. The tonalite may represent an earlier plutonic unit as suggested by Hope and Woodend (1986) on the basis of more definitive field relations for tonalite in the Port Mouton (or Port Joli) Pluton to the east.

Based on the present sampling, which includes virtually all known outcrops within the pluton, internal compositional variations appear to be unsystematic, and the pluton cannot be subdivided into mappable monzogranite, granodiorite, or tonalite areas. Of 80 samples for which quantitative modal analyses were done as part of this study, $65 \%$ are monzogranite, $27 \%$ are granodiorite, and $8 \%$ are tonalite.

Other heterogeneities also are present in the pluton. Layers alternately enriched and depleted in biotite occur locally in monzogranite, granodiorite, and tonalite, and appear to be a result of flowage segregation. Other evidence of flow is the alignment of microcline phenocrysts which occur in locally developed porphyritic areas 


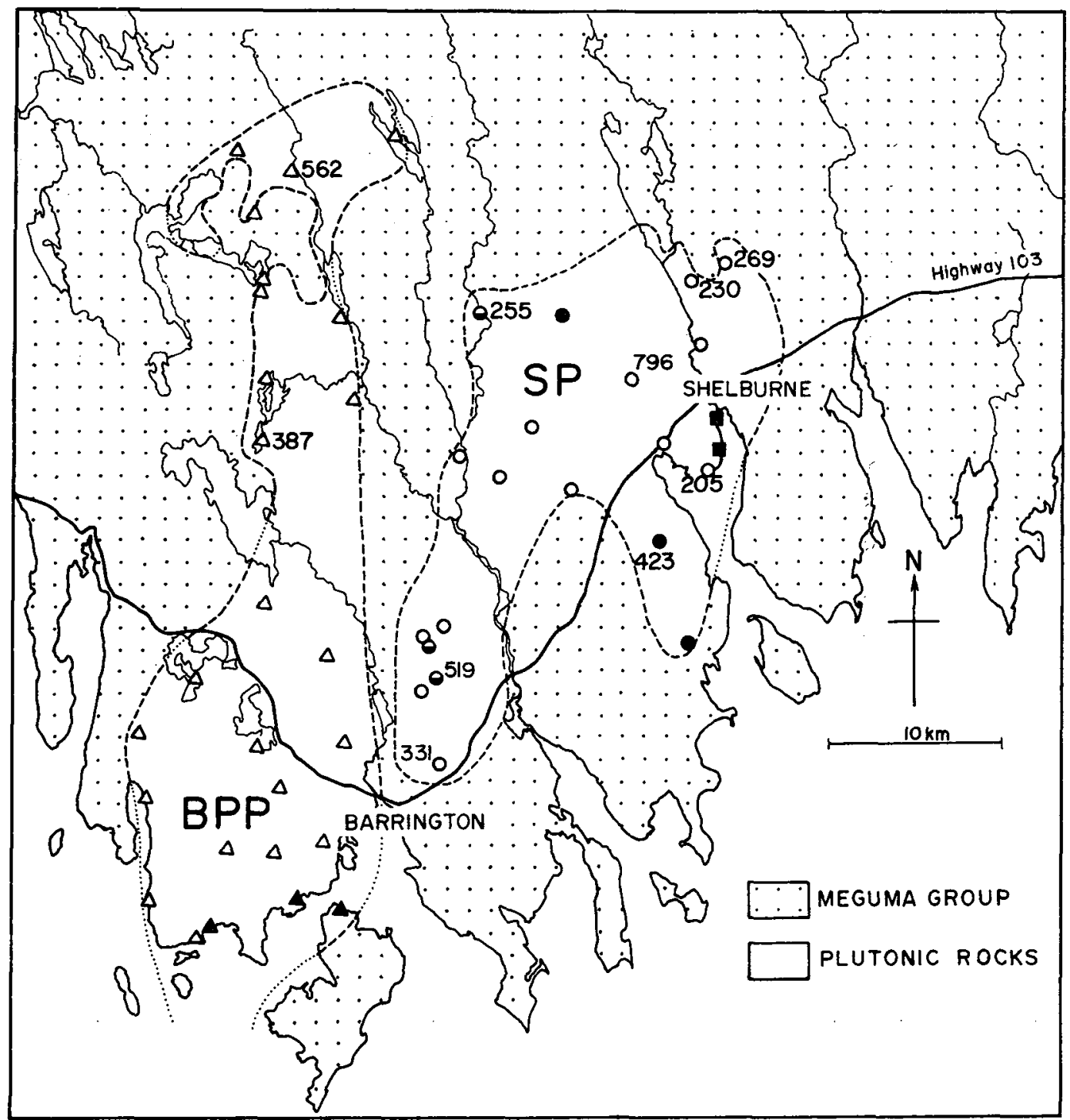

F1g. 2. Locations of analyzed samples in the Barrington Passage (BPP) and Shelburne (SP) plutons. Open triangles, Barrington Passage tonalite; open circles, Shelburne monzogranite; shaded circles. Shelburne granodicrite; half-shaded circles, Shelburne tonalite. Numbered locallties are samples for REE analysis and/or Rb-Sr dating. Other symbols represent samples from de Albuquerque (1977): shaded triangles, Barrington Passage tonalite; shaded squares, Shelburne granodiorite.

within the monzogranite. In addition, the pluton displays a weakly developed but penetrative mineral foliation defined by biotite and muscovite alignment and quartz elongation, which may be tectonic in origin. Granitic pegmatite (locally containing garnet and bery1) and aplite (commoniy garnet-bearing) dykes are common in the pluton, especially near the margins, and in the adjacent metamorphic rocks. In some areas within the pluton, sheets and pendants of metasedimentary material are numerous.

The major mineral assemblage in the monzogranite and granodiorite is quartz, potassium feldspar, plagioclase, biotite, and muscovite. Texture is typically medium-grained hypidiomorphic inequigranular with quartz and K-feldspar interstitial to plagioclase and mica but locally the monzogranite is porphyritic, with microcline phenocrysts. Biotite content ranges from less than $1 \%$ to $20 \%$, and tends to be higher in the granodiorite (average $11 \%$ ) than in the monzogranite (average $7 \%$ ). Muscovite is present in all of the monzogranite samples and most of the granodiorite samples, ranging up to $13 \%$ of the rock and averaging about $7 \%$. Much of the muscovite occurs as large separate flakes which are interpreted to be of primary (magmatic) origin. However, secondary sericitic muscovite is also abundant. Accessory minerals include zircon, sphene, apatite, monazite, rutile, opaque minerals, and rarely garnet. Microprobe analyses indicated that the opaque minerals are ilmenite. Alteration is not intense, but most samples contain partially chloritized biotite and variable amounts of sericite and saussurite in the feldspars.

The tonalite samples consist of plagloclase, quartz, and biotite with hypidiomorphic granular texture. Biotite forms about $18 \%$ of the rock, and 


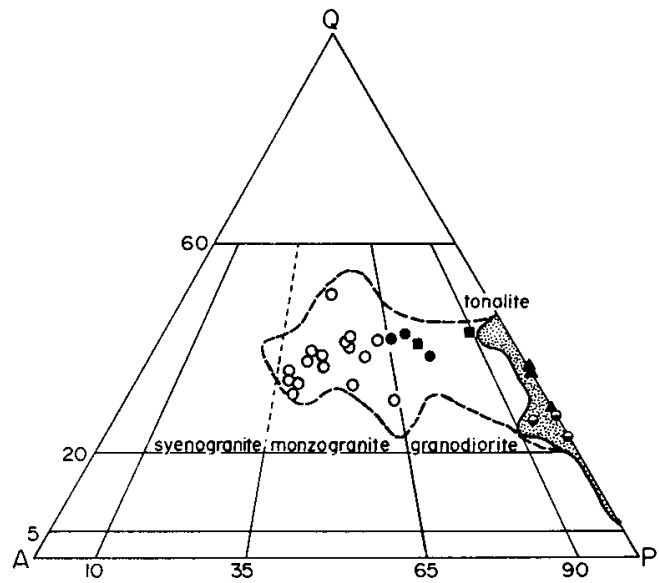

Fig. 3. Modal quartz-alkali feldspar-plagloclase diagram for samples from Shelburne and Barrington Passage plutons. Symbols as in Figure 2, except tonalite samples from the Barrington Passage Pluton are represented by the dotted area (includes 24 samples). Dashed field shows range of modal analyses for 85 samples from the Shelburne Pluton. Field names are from Streckeisen (1976).

quartz more than 20\%. Potassium feldspar is essentially absent (Fig. 3), but where present is interstitial.

\section{Geochemistry}

Means and standard deviations for geochemical data from the monzogranite, granodiorite, and tonalite of the Shelburne Pluton are presented in Table 1, and data for selected elements are displayed on silica variation diagrams (Figs. 4, 5). Silica content in the monzogranite samples ranges from about $71-75 \%$, with a mean value of $73.6 \%$. The granodiorite overlaps in silica content (mean value $73.1 \%$ ) with the monzogranite, but is notably lower in $\mathrm{K}_{2} \mathrm{O}$ and higher in $\mathrm{CaO}$ and $\mathrm{Na}_{2} \mathrm{O}$. In contrast, the Eonalites are much lower in $\mathrm{SiO}_{2}$ (average about 67\%) and show correspondingly higher values for most other oxides, except $\mathrm{K}_{2} 0$. A plot of normative anorthite, albite, and orthoclase (Fig. 6) further illustrates the range of compositions; all of the monzogranite samples plot in the granite field (as defined by Barker, 1979) on this diagram, the three granodiorite samples plot in the trondhjemite field, and the tonalites in the tonalite field. Only one of the two samples from de Albuquerque (1977), both of which he termed trondhjemite, is classified as trondhjemite according to this diagram; the other sample plots in the granite fleld, but overall appears to be transitional in chemical character between monzogranite and granodiorite (e.g., Fig. 5).

A11 of the samples are peraluminous, with the tonalite containing the lowest normative corundum values (average 1.6\%) and the monzogranite the highest values (average $3 \%$ ) (Table 1 ).

Taking all of the samples together, $\mathrm{THO}_{2}, \mathrm{Al}_{2} \mathrm{O}_{3}$, $\mathrm{Fe}_{2} \mathrm{O}_{3}, \mathrm{MgO}$, and $\mathrm{CaO}$ display negative linear correlation with $\mathrm{SiO}_{2}$ (Fig. 4). $\mathrm{Na}_{2} \mathrm{O}$ shows no systematic variation with $\mathrm{SiO}_{2}$, but ${ }^{2} \mathrm{~K}_{2} \mathrm{O}$ is much higher (and $\mathrm{CaO}$ and $\mathrm{Na}_{2} \mathrm{O}$ somewhat higher) in the monzogranite than in the granodiorite and tonalite (Figs. 4, 5). However, excluding the granodiorite and tonalite samples, the Shelburne Pluton overall is not anomalously high in $\mathrm{Na}_{2} \mathrm{O}$ and low in $\mathrm{K}_{2} \mathrm{O}$ compared to the South Mountain Batholith, contrapy to the conclusion of de Albuquerque (1977), which was based on very limited (and unrepresentative) sampling.

Trace element data from the monzogranite and granodiorite typically show wider variation than the major elements, as 1llustrated by Figure 5 and the large standard deviations in Table 1 . For most elements, the abundance in the tonalite samples overlaps the range in the other groups, but the tonalite consistently has higher $\mathrm{Sr}, \mathrm{V}$, and $\mathrm{F}$ and lower $\mathrm{Rb}, \mathrm{Pb}$, Th, $\mathrm{U}$ and $\mathrm{Y}$. $\mathrm{Rb} / \mathrm{Sr}$ ratios show $\mathrm{a}$ wide range (Fig. 7).

Rare-earth element data (Table 2) display moderate light element (LREE) enrichment, comparatively flat heavy REE (HREE) patterns, and except in the tonalite, negative Eu anomalies (Fig. 8). The three monzogranite samples, all of which have similar silica contents of about $73 \%$, show similar overall REE patterns but considerable varlation in abundance. The two granodiorite samples from de Albuquerque (1977) have essentially the same pattern as monzogranite sample 331 , but with a smaller negative Eu anomaly. The REE patterns are virually identical to the average pattern from monzogranite of the South Mountain Batholith, using data from Muecke and Clarke (1981). Patterns for the two tonalite samples are also similar, except that they display positive Eu anomalies.

\section{BARRINGTON PASSAGE PLUTON}

\section{Field Relations and Petrography}

The Barrington Passage Pluton consists of tonalite, gradational to quartz diorite (Fig. 3). Locally mineral banding is well developed, with mafic (biotite-rich) schleiren generally aligned paralle1 to mineral foliation in the pluton. Foliation, defined by biotite alignment and elongation of quartz and feldspar grains, is ubiquitous and moderately to strongly developed. It is oriented dominantly parallel to regional trends in the host metasedimentary rocks, and is interpreted to be of tectonic origin rather than the result of flow. Granitic pegmatite dykes are common in the tonalite and adjacent metamorphic rocks, but their relationship to similar dykes in the Shelburne Pluton is not known.

The tonalite consists of plagioclase, quartz, biotite, and microcline, with average abundances in 75 samples used for modal analysis of $48,26,25$, and less than $1 \%$, respective1y. Amphibole was not observed, although its presence at one locality was reported by Reynolds et al. (1987). Texture is medium-grained hypidiomorphic granular, with quartz interstitial to plagioclase and biotite. Accessory phases include apatite, sphene, zircon, and opaque minerals. Minor muscovite of possible magmatic origin occurs locally. Alteration is generally slight to moderate, and secondary materials are mainly chlorite, sericite, and saussurite.

\section{Geochemistry}

Twenty-four samples were analyzed from the Barrington Passage Pluton. They show a wide range in $\mathrm{SiO}_{2}$ content, from $61-72 \%$ (Table 1 ; Figs. 4, 5), 
Table 1. Means and standard deviations of chemical datat and CIPW normative mineralogy for sample groups from the Shelburne and Barrington Passage plutons.

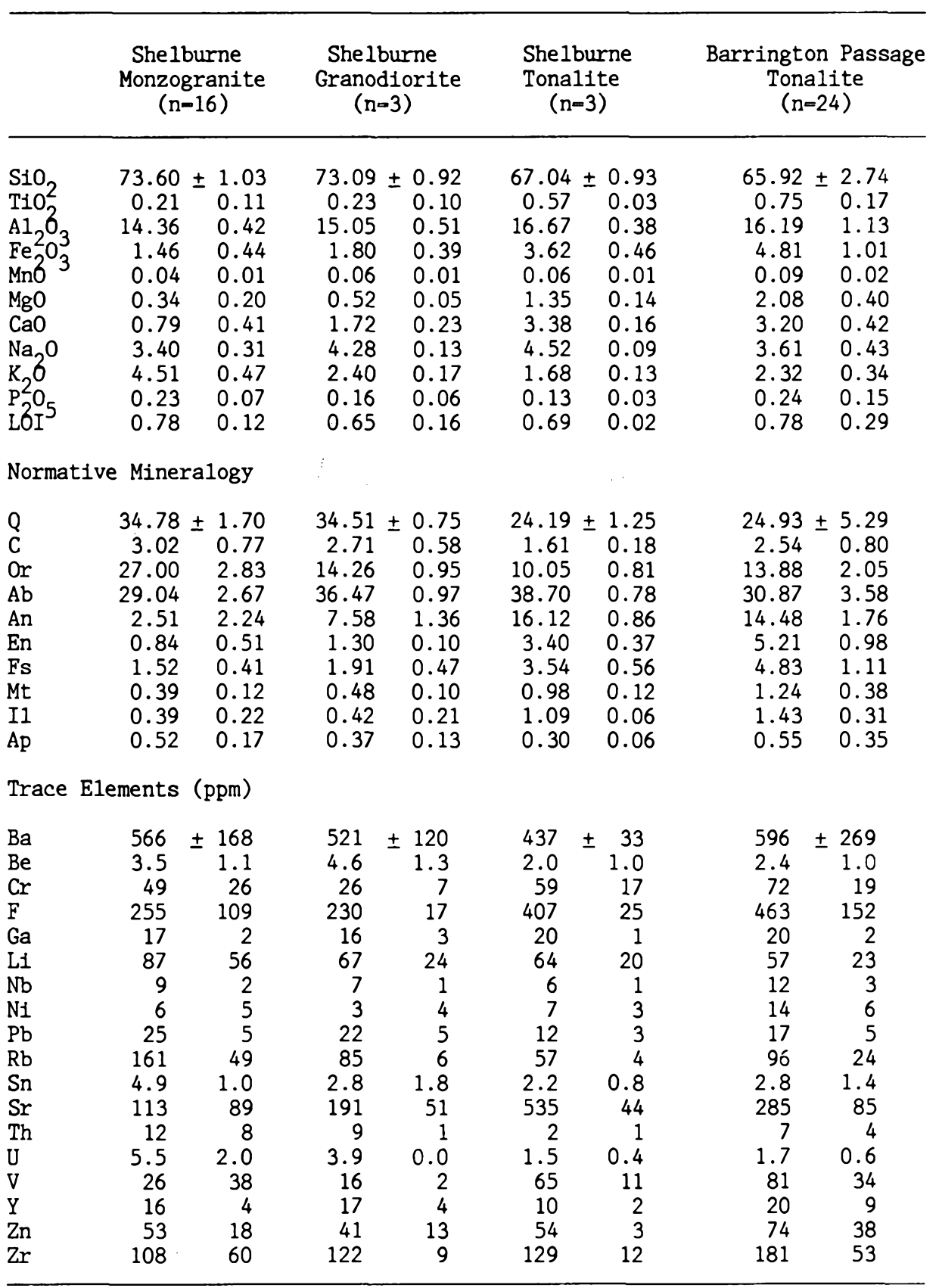

* Major element analyses by atomic absorption spectrometry, Department of Geology, Acadia University; analysts J. Cabilio and D. Rogers. Trace elements $\mathrm{Ba}, \mathrm{Cr}, \mathrm{Ga}, \mathrm{Ni}, \mathrm{Pb}, \mathrm{Rb}, \mathrm{Sr}, \mathrm{Th}, \mathrm{V}, \mathrm{Y}, \mathrm{Zn}$, and $\mathrm{Zr}$ by $\mathrm{X}-\mathrm{ray}$ fluorescence on pressed powder pellets, Nova Scotia Regional XRF Centre, St. Mary's University; chief analyst $K$. Cameron. $U$ by neutron activation, Atomic Energy Commission of Canada, Ottawa. Be, F, L1, and $\mathrm{Sn}$ by quantitative emission spectrography, Minerals Engineering Centre, Technical University of Nova Scotia; chief analyst C. Cole. 

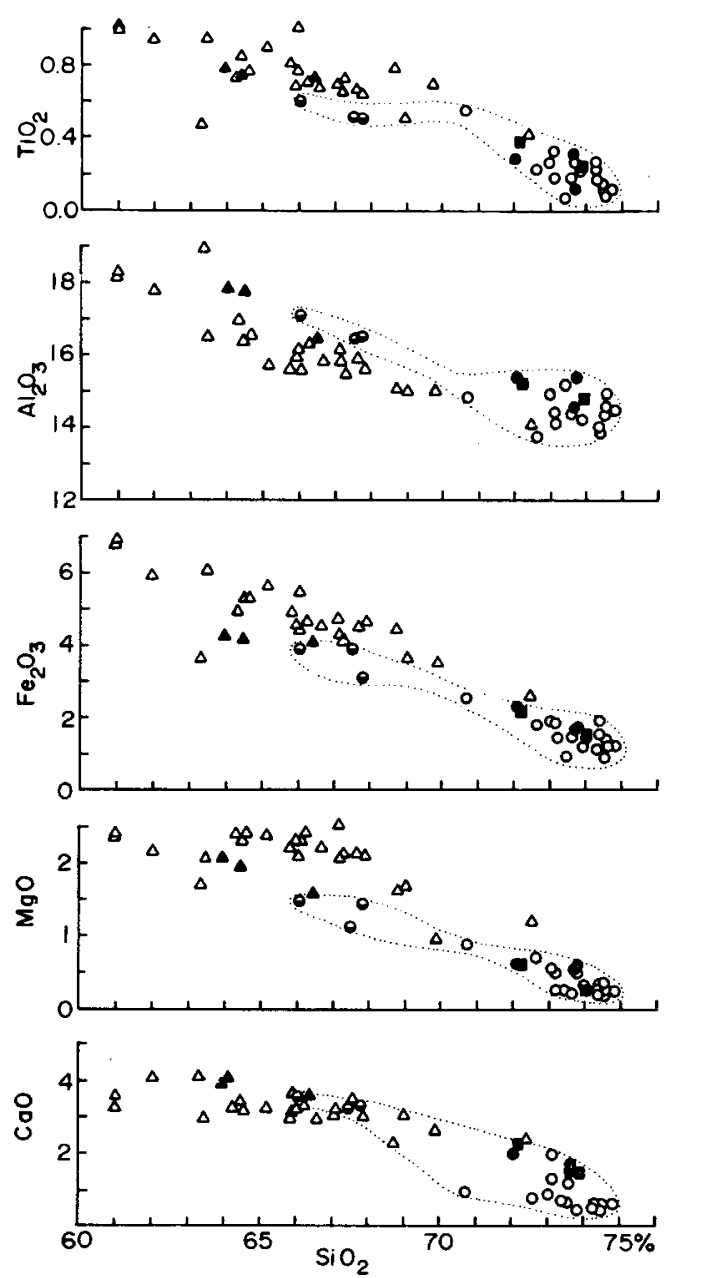

Fig. 4. Silica variation diagrams for selected major element oxides (in weight \%). Symbols as in Figure 2. Dotted field encloses all samples from the Shelburne Pluton to emphasize trends.

consiscent with their wide range in modal quartz content, but all are characterized by low $\mathrm{K}_{2} \mathrm{O}$ ( $\mathrm{Fig}$. $5)$. The $\mathrm{K}_{2} \mathrm{O}$ values display negative correlation with $\mathrm{SiO}_{2}$, as do $\mathrm{TiO}_{2}, \mathrm{Al}_{2} \mathrm{O}_{3}, \mathrm{Fe}_{2} \mathrm{O}_{3}, \mathrm{MgO}$, and $\mathrm{CaO}$. $\mathrm{Na}_{2} \mathrm{O}$ and $\mathrm{P}_{2} \mathrm{O}_{5}$ do not show clear erends. Most of these trends do not pass through the tonalite samples from the Shelburne Pluton, which tend to contain lower $\mathrm{Fe}_{2} \mathrm{O}_{3}, \mathrm{MgO}$, and $\mathrm{K}_{2} \mathrm{O}$, and higher $\mathrm{Al}_{2} \mathrm{O}_{3}, \mathrm{CaO}$, and $\mathrm{Na}_{2} \mathrm{O}$. Most of the Barrington Passage samples plot in the granodiorite field in terms of normative composition (Fig. 6), because $\mathrm{K}_{2} \mathrm{O}$ is assigned to orthoclase in the calculation of the normative mineralogy, although it resides in mica in these rocks. All of the samples are peraluminous, containing between $1 \%$ and $4 \%$ normative corundum, with an average of $2.5 \%$.

Like $\mathrm{K}_{2} \mathrm{O}, \mathrm{Rb}$ and $\mathrm{Ba}$ show pronounced negative correlation with $\mathrm{SiO}_{2}$, whereas $\mathrm{Sr}$, like $\mathrm{CaO}$, decreases only slight1y with increasing $\mathrm{SiO}_{2}$ (Fig. 5). Compared to the Shelburne tonalite, the Barrington Passage tonalite is much lower in $\mathrm{Sr}$ and higher in $\mathrm{Rb}$ (Fig. 5). Two samples from the Barrington Passage Pluton contain anomalously high $\mathrm{Rb}$ and low $\mathrm{Sr}$ compared to other samples, resulting in a high $\mathrm{Rb} / \mathrm{Sr}$ ratio; otherwise the samples show
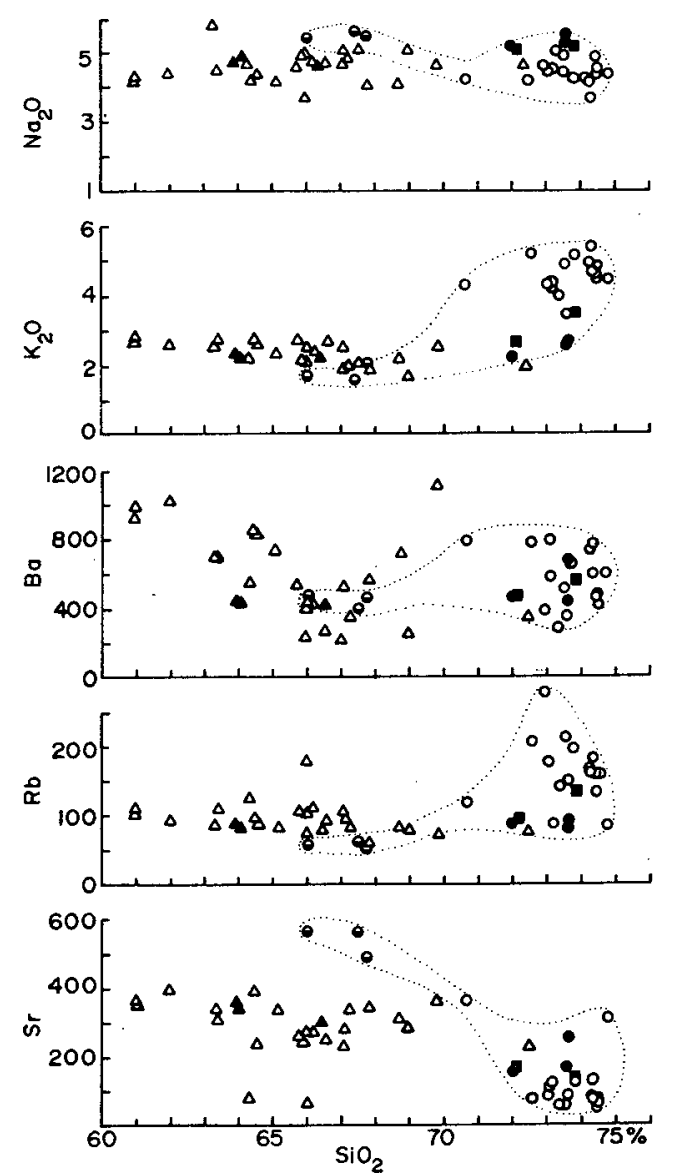

Fig. 5. Silica variation diagrams for $\mathrm{Na}_{2} \mathrm{O}$ and $\mathrm{K}_{2} \mathrm{O}$ (in weight \%) and $\mathrm{Ba}, \mathrm{Rb}$, and $\mathrm{Sr}$ (in ppm). ${ }^{2}$ Symbols as in Figure 2. Dotted field encloses all samples from the Shelburne Pluton to emphasize trends.

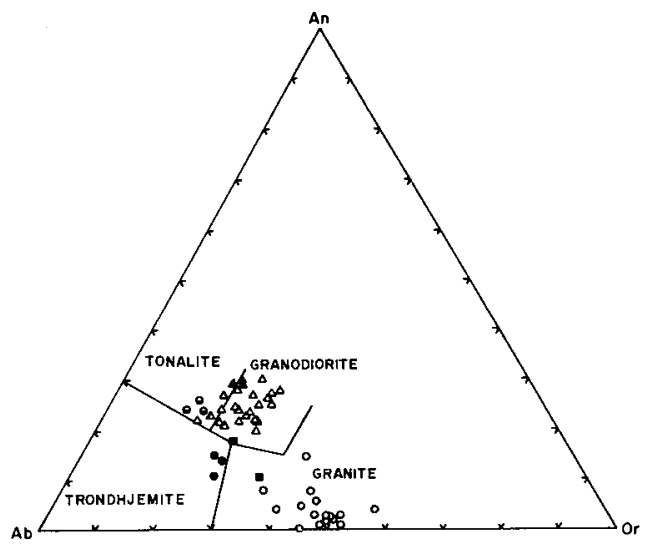

Fig. 6. Normative anorthite-albite-orthoclase ternary diagram with fields from Barker (1979). Symbols as in Figure 2.

little variation in $\mathrm{Rb} / \mathrm{Sr}$ ratio with $\mathrm{SiO}_{2}$ content (Fig. 8). One of the two anomalous samples is from the northern part of the pluton and the other from the south; neither appears anomalous in terms of modal mineralogy so the significance of the anomalous $\mathrm{Rb}$ and $\mathrm{Sr}$ data is not known.

Most other trace elements (Be, Cr, F, Ga, L1, Nb, 


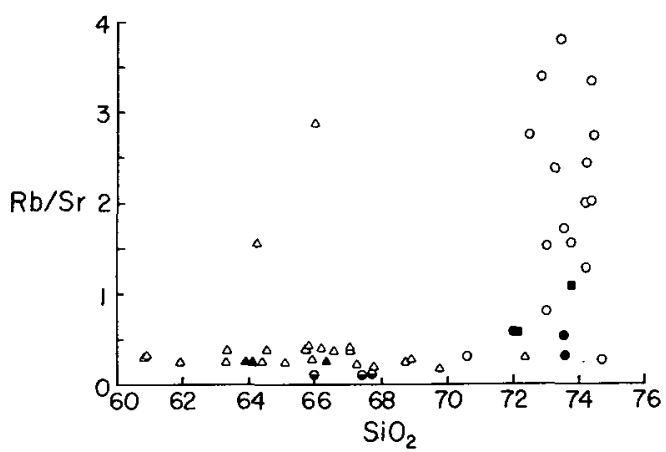

F1g. 7. P1ot of $\mathrm{Rb} / \mathrm{Sr}$ against $\mathrm{SiO}$ for samples from the Shelburne and Barrington Passage plutons. Symbols as in Figure 2.

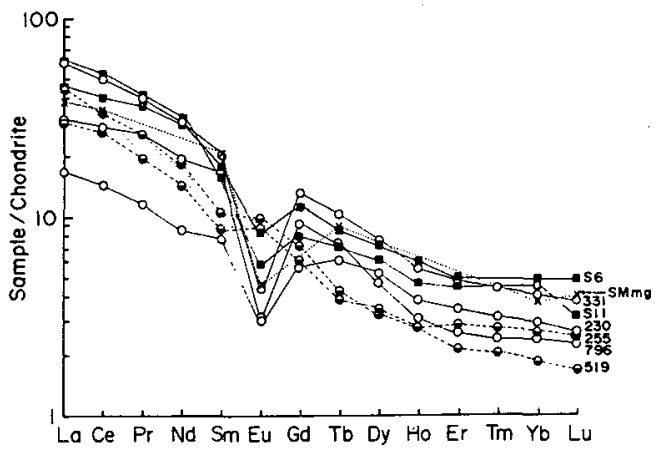

Fig. 8. Chondrite-normalized rare-earth element data (from Table 2) for the Shelburne Pluton with symbols as in Figure 2. Tonalite samples 255 and 519 are separated by stippled area to emphasize their trend. Average pattern for monzogranite of the South Mountain Batholith (SMmg) from Muecke and Clarke (1981) is shown for comparison. All samples are normalized relative to chondritic values of Taylor and McLennan (1985).

Table 2. Rare-earth element data* for samples from the Shelburne (230 - S-11) and Barrington Passage (387 - S-112) plutons. Samples 230, 331, and 796 are monzogranite; S6 and S-11 are granodiorite; 255, 519, and all of the Barrington Passage Pluton samples are tonalite.

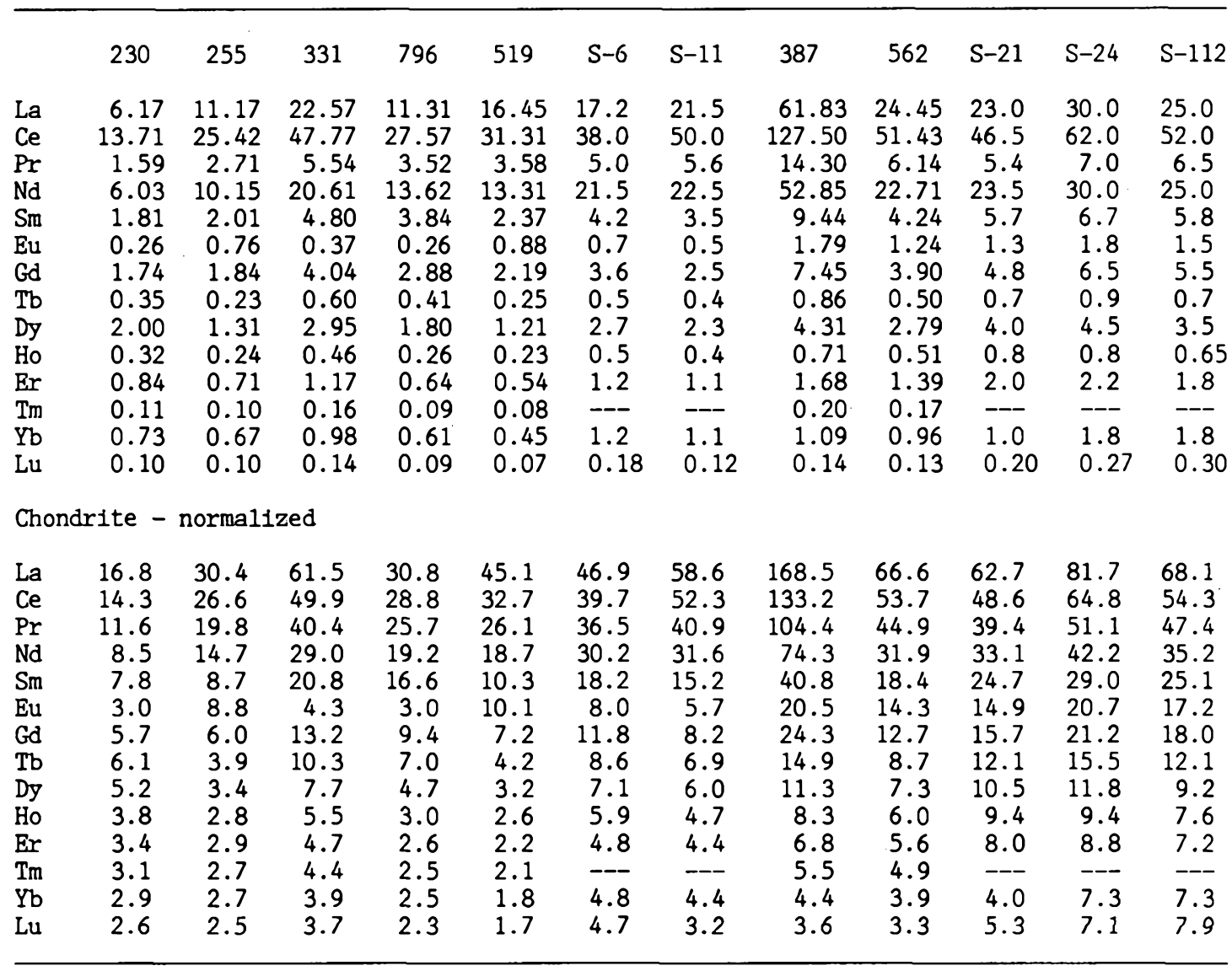

* Data for samples S-6, S-11, S-21, S-24, and S-112 from de Albuquerque (1977). Other data by inductively coupled plasma mass spectrometry (ICP-MS), Department of Earth Sciences, Memorial University of Newfoundland. Chondrite normalizing values from Taylor and McLennan (1985). 
$\mathrm{Ni}, \mathrm{Pb}, \mathrm{V}, \mathrm{Y}, \mathrm{Zn}, \mathrm{Zr}$ ) show negative correlation with silica content (plots not shown), and the data are much less scattered than in the Shelburne Pluton.

Rare-earth element data (Table 2), both from this study and from de Albuquerque (1977), show chondrite-normalized patterns very similar to those for the Shelburne Pluton samples, except that the total REE abundance, especially for HREE, tends to be greater in the Barrington Passage samples, and the negative Eu anomaly is much less pronounced (Fig. 9).

\section{AGE OF THE PLUTONS}

The ages of emplacement of the Shelburne and Barrington Passage plutons are not yet resolved in spite of numerous dating studies. Some data have suggested that the plutons may be younger than the South Mountain Batholith, and perhaps Carboniferous in age (Fairbairn et al., 1960; Reynolds et al., 1981; Dallmeyer and Keppie, 1987). However, Devonian ages (370-400 Ma) appear to be more 11kely (Dallmeyer and Kepple, 1987; Reynolds et al., 1987).

An attempt to obtain a $\mathrm{Rb}-\mathrm{Sr}$ age from a sulte of samples from the Barrington Passage Pluton ylelded no rellable isochron, but suggested a minimum age of about $400 \mathrm{Ma}$ (J. Blenkinsop, personal communication, 1987). For the Shelburne Pluton, four whole-rock samples suggest an age of $466 \pm 17$ $\mathrm{Ma}$, with an initial ratio of $0.7034 \pm 0.0010$ and MSWD (Brooks et al., 1972) of 11 (Table 3, Fig. 10). However, this age may not be rellable if the $\mathrm{Rb}-\mathrm{Sr}$ system was not homogenized during anatexis, or has been disturbed, a 1ikely posstbility because of the documented occurrence of younger thermal events in the area (Dallmeyer and Kepple, 1987; Reynolds et al., 1987). Younger cooling ages for the Shelburne Pluton compared to cooling ages in adjacent metamorphic rocks suggest that it may post-date regional metamorphism, consistent with its cross-cutting relationship with regional metamorphic 1sograds (Raeside et al., 1985), but not with the interpretation of Wentzell (1985) who inferred a pre-Acadian contact metamorphic event adjacent to the pluton.

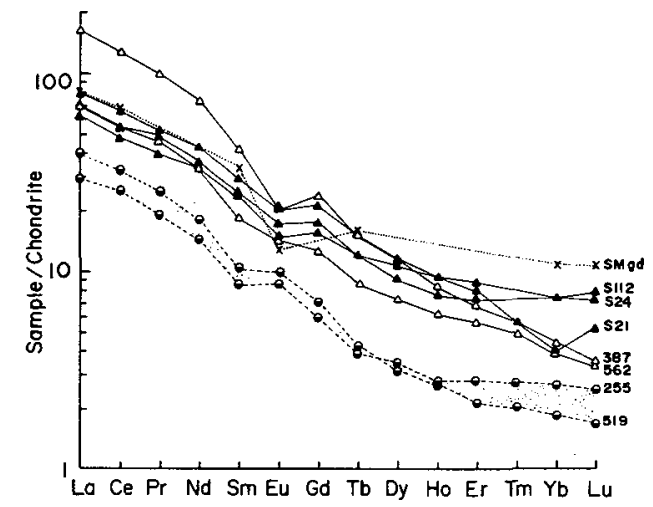

Fig. 9. Chondrite-normalized rare-earth element data (from Table 2) for the Barrington Passage tonalite with symbols as in Figure 2. Patterns for Shelburne tonalite samples 255 and 519 (separated by stippled pattern to emphasize trend) and average South Mountain granodiorite (SMgd) from Muecke and Clarke (1981) are shown for omparison. A11 data are normalized relative to hondritic values from Taylor and McLennan (1985).

\section{DISCUSSION}

Phanerozolc tonalitic plutons were typically formed in association with subduction zones, and their origin has been generally linked to melting of basaltic source rocks (e.g., Barker, 1979). However, the Barrington Passage tonalite differs from such tonalites in the almost ubiquitous absence of amphibole, in its trace element composition, and in its REE pattern. The typical REE pattern for tonalitic rocks derived from mafic source rocks or from evolution of mafic magmas shows a positive Eu anomaly and a flat HREE pattern (e.g., Arth, 1979). The data from this study support the conclusions of de Albuquerque (1977), who showed that the mineralogy and chemistry (including the REE pattern) of the Barrington Passage tonalite are consistent with derivation from a metasedimentary source, in particular greywacke.

Similarly, mineralogical and chemical features of the Shelburne Pluton, such as the abundance of biotite and muscovite and strong1y peraluminous composition, suggest that the source rocks were also metasedimentary. Longstaffe et al. (1980) reported $\delta^{18} 0$ values between 8.3 and 10.8 , in the Shelburne and Barrington Passage plutons, with little difference between the two plutons, and suggested that both were derived from a metasedimentary source region with lower $\delta^{18} 0$ than

Table 3. Isotopic data* for $\mathrm{Rb}$ and $\mathrm{Sr}$ for monzogranite samples from the Shelburne Pluton.

\begin{tabular}{lcrcc}
\hline $\begin{array}{l}\text { Sample } \\
\text { Number }\end{array}$ & $\begin{array}{c}\mathrm{Rb} \\
(\mathrm{ppm})\end{array}$ & $\begin{array}{c}\mathrm{Sr} \\
(\mathrm{ppm})\end{array}$ & $\begin{array}{c}{ }^{87} \mathrm{Rb} /{ }^{86} \mathrm{Sr} \\
(\text { atomic })\end{array}$ & $\begin{array}{c}{ }^{87} \mathrm{Sr} /{ }^{86} \mathrm{Sr} \\
(+2 \mathrm{~S} . \mathrm{D} .)\end{array}$ \\
\hline 205 & 197 & 133 & 4.273 & $0.73306(0.00027)$ \\
269 & 162 & 45 & 10.335 & $0.77110(0.00010)$ \\
331 & 165 & 88 & 5.403 & $0.73914(0.00008)$ \\
423 & 99 & 118 & 2.431 & $0.71937(0.00007)$ \\
\hline
\end{tabular}

* Analyses by Geochron Laboratories Division, Krueger Enterprises Inc., Cambridge, Massachusetts.

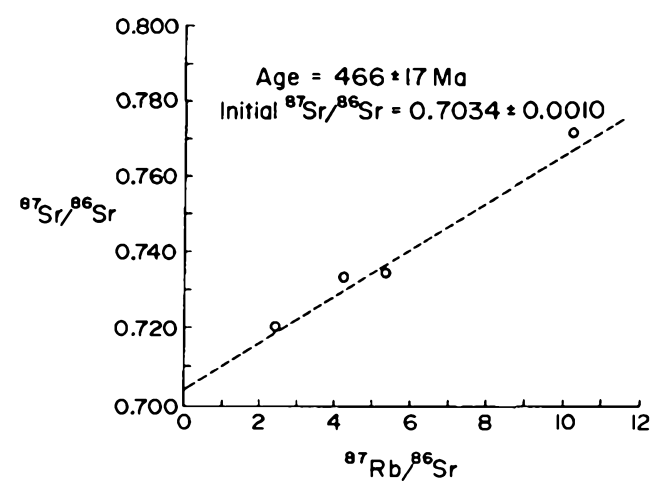

Fig. 10. Rb-Sr whole-rock errorchron (Brooks et al.. 1972; York, 1969) for four samples from the Shelburne granite and granodiorite. Data from Table 3. 
the source rocks for the South Mountain Batholith, possibly as a result of exchange with mafic magmas $87_{10} 5^{\circ}$, or during, anatexis. If the low initial ${ }_{\mathrm{Sr}} /{ }^{85} \mathrm{Sr}$ ratio suggested by the $\mathrm{Rb}-\mathrm{Sr}$ isochron is correct, it too supports a very non-radiogenic source for the magmas. Recent recognition of mafic granulite facies rocks within the Meguma Terrane (Giles and Chatterjee, 1987) is possible evidence for the existence of appropriate source rocks beneath southern Nova Scotia. Varied small mafic plutons in the region of the Shelburne and Barrington Passage plutons (e.g., Taylor, 1967; de Albuquerque, 1979; Rogers, in preparation) are further evidence for complex lower Crust and/or upper Mantle involvement in petrogenesis in this area, although age data do not provide evidence concerning possible consanguinity of all of these magma types.

Variations within the Shelburne Pluton are consistent with a co-magmatic relationship between the monzogranite, granodiorite, and tonalite, using an evolutionary model involving mainly plagloclase and biotite fractionation. For example, trends of decreasing $\mathrm{Ba}$ are consistent with biotite fractionation, whereas strong $\mathrm{Sr}$ depletion suggests plagloclase removal ( $\mathrm{Fig}$. 11). The latter is in keeping with the strong negative Eu anomaly developed in the granodiorite and monzogranite. Relative accumulation of K-feldspar is consistent with the trend towards high $\mathrm{K}_{2} \mathrm{O}, \mathrm{Rb}$, and $\mathrm{Rb} / \mathrm{Sr}$ ratio, (Figs. 7, 11). The tonalite could be the result of plagioclase accumulation, which would explain both its high $\mathrm{Sr}$ content and silghtly positive Eu anomaly. The relatively small size of the positive Eu anomaly can be explained if the parent magma already had a negative Eu anomaly, as suggested by de Albuquerque (1977) as a result of derivation from metasedimentary source rocks with plagioclase in the residuum. Because the blotite in the pluton contains abundant zircon, biotite fractionation would also involve zircon fractionation, and this would contribute to depletion in HREE.

This mode1 is similar to that suggested by Muecke and Clarke (1981) for the South Mountain Batholith, and is compatible with the similarity between REE patterns in the South Mountain monzogranite and Shelburne monzogranite/granodiorite (Fig. 8), although the oxygen 1sotope data indicate that these intrusions were not co-magmatic. The model is not in agreement with that of de Albuquerque (1977), who suggested that differentiation could not explain the chemical trends that he observed in the Shelburne and associated plutons. However, his interpretation was based on a limited number of samples which did not display trends as clearly as the present data set. Nonetheless, variable degrees of anatexis as modelled by de Albuquerque (1977) may contribute to the chemical variation in the pluton.

In contrast to the Shelburne Pluton, trends in the Barrington Passage tonalite are consistent with fractionation of biotite with only minor involvement of plagioclase. Samples with highest silica tend to be lowest in $\mathrm{K}_{2} \mathrm{O}, \mathrm{Rb}$, and $\mathrm{Ba}$. The range in $\mathrm{Ba}$ contents at approximately constant $\mathrm{Sr}$ indicates biotite fractionation (Fig. 11). Constant $\mathrm{Rb} / \mathrm{Sr}$ ratio over a wide range of silica contents (Fig. 7) also suggests that feldspar was not significantly involved in the differentiation
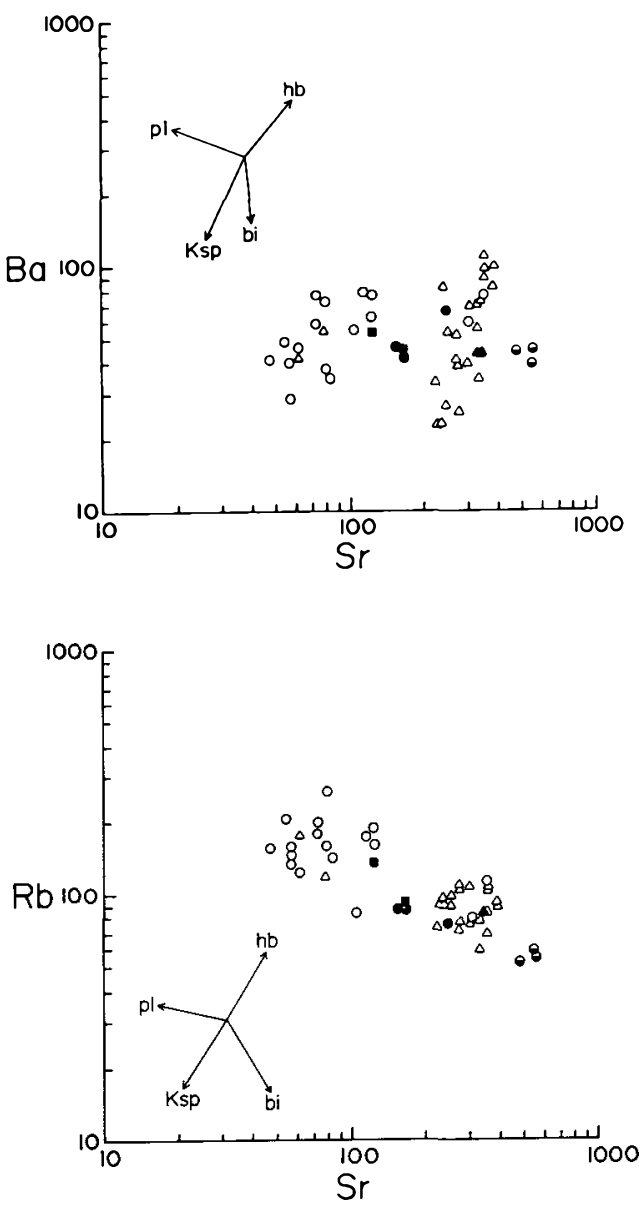

Fig. 11. Ba-Sr and $\mathrm{Rb}-\mathrm{Sr}$ plots for samples from the Sheiburne and Barrington Passage plutons. Symbols as in Figure 2. Fractionation vectors for plagioclase (p1). hornblende (hb), K-feldspar (Ksp) and biotite (bi) are inferred from Tindle and Pearce (1981) and Atherton and Sanderson (1985).

process. Ne1ther chemical nor petrographic data provide any evidence for hornblende involvement. A minor role for plagioclase is also suggested by the absence of a pronounced negative Eu anomaly, although if the tonalite magma originally had a positive Eu anomaly as a result of derivation from a hornblende-bearing source and a major contribution from plagloclase anatexis (to produce a tonalitic me1t), then subsequent plagioclase fractionation could have resulted in essentially no $\mathrm{Eu}$ anomaly. Other than the difference in Eu anomaly and somewhat less HREE depletion, the Barrington Passage REE pattern is similar to that for the average granodiorite from the South Mountain Batholith (Fig. 9).

A major question is whether or not the Shelburne and Barrington Passage plutons were co-magmatic. The chemical data suggest that this is possible. with the granodiorite-monzogranite resulting from dominantiy plagioclase fractionation in contrast to the variation in the Barrington Passage tonalite controlled mainly by biotite fractionation. However, given the minor abundance of intermediate (granodioritic) compositions, it seems more likely that variable degrees of anatexis of similar source rocks (de Albuquerque, 1977) is a better 
explanation for the two separate plutons (which may or may not be of similar age).

The tectonic setting in which these plutons formed is not clear. Low values of $\mathrm{Rb}$ as well as $\mathrm{Y}$ $\pm \mathrm{Nb}$ in the Shelburne and Barrington Passage plutons indicate that these are "volcanic-arc granites" according to the criteria of Pearce et al. (1984), suggesting that the magmas may have been generated in a subduction environment. Equivalent data have not yet been published for South Mountain Batholith, but rocks of similar $\mathrm{SiO}_{2}$ content appear to have higher $\mathrm{Rb}$ (but not $\mathrm{K}_{2} \mathrm{O}$ ) (data in Smith, 1979) compared to the Shelburne monzogranite-granodiorite, and hence are 11 kely to fall in the syn-collision granite field of Pearce et al. (1984). A syn-collisional setting is more consistent with inferred tectonic regimes in southern Nova Scotia during the Devonian (e.g., Keppie, 1982) than is subduction. However, a subduction environment was also inferred by de Albuquerque (1979) for the more mafic intrusions of probable Devonian age in the Shelburne - Barrington Passage area, and hence the possibility of Devonian subduction under southern Nova Scotia cannot be discounted.

In conclusion, until the intrusive ages are clarified, petrogenetic interpretations comparing or relating the Shelburne and Barrington Passage plutons to one another, to the other plutons in adjacent areas, to the South Mountain Batholith, and to tectonic regimes in southern Nova Scotia are only speculative. However, the petrochemical data presented here are not incompatible with petrogenesis similar to that of the South Mountain Batholith.

\section{ACKNOWLEDGEMENTS}

Much of the funding for this project was provided by the Geological Survey of Canada through the Canada - Nova Scotia Co-operative Mineral Program (1981-84). We are grateful for this support. We thank Chris White for his assistance in the field, and Rob Raeside and his Honours students for their interpretations of the metamorphic history of the metasedimentary units in the study area. The manuscript was much improved as a result of constructive reviews by two journal referees.

ARTH, J.G. 1979. Some trace elements in trondhfemites-their $1 \mathrm{mplications}$ to magma genesis and paleotectonic setting. In Trondhfemites, Dacites, and Related Rocks. Edited by F. Barker. Elsevier. New York, pp. 123-132.

ATHERTON, M.P. and SANDERSON, L.M. 1985. The chemical variation and evolution of the superunits of the segmented Coastal Batholith. In Magmatism at a Plate Edge: the Peruvian Andes. Edited by W.S. . P1tcher, M.P. Atherton. E.J. Cobbing and R.D. Beckinsale. Blackie, Glasgow, pp. 208-227.

BARKER F. 1979. Trondhjemite: definition, environment, and hypotheses of origin. In Trondhjemites, Dacites, and Related Rocks. Edited by F. Barker. E1sevier, New York, pp. 1-12.

BOURQUE, A.D. 1985. Migmatization and metamorphism associated w1th the Barrington Passage Pluton, Shelburne and Yarmouth counties, Nova Scotia. B.Sc. thesis, Acadia University, Wolfville, Nova Scotia.

BROOKS, C., HART, S.R., and WENDT, I. 1972. Realist1c use of two-error regression treatment as applied to rubldiumstrontium data. Review of Geophysics and Space Physics, 10, 551-557.

CHU, P. 1978. Metamorphism of the Meguma Group in the Shelburne area, Nova Scotia. M.Sc. thesis, Acadia University, Wolfville, Nova Scot1a, 106 p.

DALLMEYER, R.D.. and KEPPIE, J.D. 1987. Polyphase late Paleozo1c tectonothermal evolution of the southwestern Meguma Terrane, Nova Scot1a: evidence from ${ }^{40} \mathrm{Ar} /{ }^{39} \mathrm{Ar}$ mineral ages.
Canadian Journal of Earth Sclences, 24, pp. 1242-1254.

de ALBUQUERQUE, C.A.R. 1977. Geochemistry of the tonalitic and granitic rocks of the Nova Scotia southern plutons. Geochimica et Cosmochimica Acta, 41, pp. 1-13.

de ALBUQUERQUE, C.A.R. 1979. Origin of the plutonic mafic rocks of southern Nova Scot1a. Geological Soclety of Amerlca Bulletin, Part I. 90, pp. 719-731.

FAIRBAIRN, H.E. HURLEY, P.M. . PINSON, W.H. J J. , and CORMIER R.F. 1960. Age of gran1t1c rocks of Nova Scot1a. Geological Soclety of America Bullet1n, 71, pp. 399-414.

GILES, P. , and CHATTERJEE, A.K. 1987. Lower crustal xenocrysts and xenoliths in the Tangler Dyke, eastern Meguma Zone, Nova Scotia. In Mines and Minerals Branch, Report of Activities 1987, Part A. Edited by J.L. Bates and D.R. MacDonald. Nova Scotia Department of Mines and Energy. Report 87-5, pp. 85-88.

HANSON, G.N. 1978. Rare earth elements in petrogenet1c studies of 1gneous systems. Annual Reviews of Earth and Planetary Science, 8, pp. 371-406.

HASKIN I.A. HASKIN, M.A. and FREY, F.A. 1968. Relative and absolute terrestrial abundances of the rare earths. In Origin and Distribution of the Elements. Edited by L.H. Ahrens. Pergamon, Oxford, pp. 889-912.

HOPE, T.L., and WOODEND, S.L. 1986. Geological mapping and 1gneous and metamorphic petrology. Queen's and Shelburne count1es, Nova Scot1a. In Current Research, Part A, Geological Survey of Canada. Paper 86-1A. pp. 429-433.

KEPPIE, J.D. 1979. Geological map of the province of Nova Scotia. Nova Scot1a Department of Mines and Energy, Halifax, Nova Scot1a, Scale 1:500,000.

KEPPIE, J.D. 1982. The Minas Geofracture. In Major Structural Zones and Faults of the Northern Appalachians. Edited by $\mathrm{P}$. St. Julien and J. Beland. Geological Association of Canada. Spec1al Paper 24, pp. 263-280.

KEPPIE J.D. and MUECKE, G.K. 1979. Metamorph1c map of Nova Scotia. Nova Scotia Department of Mines and Energy. Halifax. Nova Scotia, scale $1: 1,000,000$.

LONGSTAFFE, F.J. . SMITH, T.E., and MUEHLENBACHS, K. 1980. Oxygen 1sotope evidence for the genesis of Upper Paleozolc gran1to1ds from southwstern Nova Scot1a. Canadian Journal of Earth Sciences, 17, pp. 132-141.

MUECKE, G. K.., and CLARKE. D.B. 1981. Geochemical evolution of the South Mounta1n Batholith, Nova Scot1a: rare-earth-element evidence. Canadian Mineralogist, 19, pp. 133-145.

PEARCB, J.A. HARRIS, N.B.W., and TINDLB, A.G. 1984. Trace element discrimination diagrams for the tectonic interpretation of granit1c rocks. Journal of Petrology. 25. pp. 956-983.

RAESIDE, R.P. . WHITE, C.E., and WENTZELL, B.D. 1985. The metamorphic development of the Shelburne complex, southwest Nova Scot1a. Geological Association of Canada, Program w1th Abstracts, 10, p. A50.

REYNOLDS, P.H. . and MUECKE, G K. 1978. Age studies on slates: applicability of the ${ }^{40} /{ }^{39}$ Ar stepwise outgassing method. Earth and Planetary Sclence Letters, 40, pp. 111-118.

REYNOLDS, P.H., ELIAS, P., MUECKE, G. , and GRIST, A.M. 1987. Thermal h/ftor $z_{9}$ of the southwestern Meguma zone. Nova Scot1a. from an ${ }^{4 r} /{ }^{39} \mathrm{Ar}$ and fission track dating study of intrusive rocks. Canadian Journal of Earth Sclences, 24, pp. 1952-1965.

REYNOLDS, P.H., ZENTILLI, M., ELIAS, P.N. . and MUBCKB, G.K. 1984. Thermal history of the southwestern Meguma Zone and Hercynian mineralization: an argon age study. Mar1time Sediments and Atlantic Geology. 20, p. 106.

REYPOLDS, P.H. . ZENTILLI, M. , and MUBCKB, G.K. 1981. K-Ar and ${ }^{\mathrm{Ar} /}{ }^{39} \mathrm{Ar}$ geochronology of granitold rocks from southern Nova Scot1a: 1ts bearing on the geological evolution of the Meguma Zone of the Appalachians. Canadian Journal of Earth Sciences 18. pp. 386-394.

ROGERS, H.D. In preparation. Petrology of the Shelburne, Barrington Passage, and other plutons in southern Nova Scot1a. M.Sc. thesis, Acadia University, Wolfville, Nova Scotia.

ROGERS, H.D. 1986. Igneous and metamorphic geology of Shelburne and eastern Yarmouth Counties, Nova Scotia. Geological Survey of Canada. Open F1le 1374.

ROGERS, H.D. 1985. Granitold rocks of Shelburne County and eastern Yarmouth County. Nova Scot1a. In Gu1de to Granites and Mineral Deposits of Southwestern Nova Scotia. Edited by A.K. Chatterjee and D.B. Clarke. Nova Scotia Department of Mines and Energy, preprint of Paper 85-3, pp. 121-130.

ROGERS, H.D., and WHITE, C.E. 1984. Geology of the 1gneousmetamorphic complex of Shelburne and eastern Yarmouth counties, Nova Scotia. In Current Research, Part A. Geological Survey of Canada, Paper 84-1A. pp. 463-465.

SMITH, T.E. 1979. The geochemistry and origin of the Devonian granit1c rocks of southwest Nova Scot1a. Geological Soc1ety of America Bulletin, Part II, 90, pp. 850-885.

STRECKEISEN, A. 1976. To each plutonic rock 1ts proper name. Earth Science Reviews. 12, pp. 1-33. 
TAYLOR, F.C. 1967. Reconnaissance geology of the Shelburne map-area, Queens, Shelburne, and Yarmouth Counties, Nova Scotia. Geological Survey of Canada, Memolr 349, 83 p.

TAYLOR, S.R.. and MCLENNAN, S.M. 1985. The Continental Crust: its Composition and Evolution. Blackwell Scientific Publications, Oxford, 312 p.

TINDLE, A.G., and PEARCE, J.A. 1981. Petrogenetic modelling of in situ fractional crystallization in the zoned Loch Doon
Pluton, Scotland. Contributions to Mineralogy and Petrology, 78. pp. 196-207.

WENTZELL, B.D. 1985. The transition from staurolite to sillimanite zone, Port LaTour, Nova Scotia. B.Sc. Honours thesis. Acadia University, Wolfville, Nova Scotia.

YORK, D. 1969. Least squares fitting of a straight line with correlated errors. Earth and Planetary Science Letters, 5. pp. 320-324. 